\title{
MENINGKATKAN KEMAMPUAN SPASIAL SISWA MELALUI PEMBELAJARAN GEOMETRI BERBANTUAN CABRI 3D
}

\author{
Eline Yanty Putri Nasution \\ Institut Agama Islam Negeri (IAIN) Padangsidimpuan, Jalan T. Rizal Nurdin Km 4,5 \\ Sihitang 22733 Telepon (0634) 22080 Faximili (0634) 24022, eline.yanty@student.upi.edu
}

\begin{abstract}
ABSTRAK
Tujuan penelitian ini adalah untuk menelaah dan mendeskripsikan peningkatan kemampuan spasial siswa yang memperoleh pembelajaran Geometri dengan menggunakan Software Geometri Dinamis, Cabri 3D. Penelitian ini merupakan kuasi eksperimen dengan desain kelompok control tidak ekuivalen. Pembelajaran konvensional diimplementasikan paka kelas kontrol sementara pembelajaran Geometri dengan menggunakan Cabri 3D diimplementasikan pada kelas eksperimen. Populasi penelitian ini adalah seluruh siswa kelas VIII SMP pada salah satu SMP Negeri di Kota Padangsidimpuan. Sampel dalam penelitian ini adalah sebanyak 2 kelas dari kelas VIII. Sampel dipilih dengan menggunakan teknik purposif sampling. Instrumen penelitian meliputi tes kemampuan, angket, observasi dan wawancara. Pengolahan data tes dianalisis secara kuantitatif dan pengolahan data non-tes dilakukan secara kualitatif untuk menjawab hipotesis bahwa peningkatan kemampuan spasial siswa yang mendapatkan pembelajaran Geometri berbantuan Cabri $3 D$ lebih baik daripada siswa yang mendapatkan pembelajaran konvenisonal.

Kata kunci: Kemampuan Spasial, Software Geometri Dinamis, Cabri 3D.
\end{abstract}

\begin{abstract}
The purpose of this study are to investigate and to describe the gain of students ${ }^{6}$ spatial ability through Geometry teaching and learning by using a dynamic geometry software, Cabri 3D. This study was a quasi experimental research with not equivalent control group design. Direct instruction was implemented in control group otherwise Geometry teaching and learning with using Cabri 3D was implemented in experimental group. The population of this study are all of the eight grade of junior high school students in one of the SMP Negeri in Padangsidimpuan City. The sample of this study were two groups of eighth grade. The sample has been choosed with using purposif sample technique. The instruments of this study were spatial ability test, quationere, observation sheet and interview. The test was analysed quantitatively and non test was analyzed qualitatively in order to answer the the hypotesa, the gain of students' spatial ability who has studied and lerant with using Cabri 3D is better than direct instruction.
\end{abstract}

Keywords: Spatial Ability, Dynamic Geometri Software, Cabri 3D. How to Cite: Nasution, E. Y. P. (2017). Meningkatkan Kemampuan Spasial Siswa
Melalui Pembelajaran Geometri Berbantuan Cabri 3D. Mathline:
Jurnal Matematika dan Pendidikan Matematika, Vol.2, No.2, 179-194. 


\section{PENDAHULUAN}

Pendidikan merupakan salah satu indikator kemajuan sebuah negara. Semakin baik kualitas pendidikan di sebuah negara maka semakin baik pula kualitas negara tersebut. Salah satu upaya untuk mencapai tujuan pendidikan adalah melalui peningkatan mutu pendidikan yang dapat dilakukan melalui kegiatan pembelajaran. Peningkatan mutu pendidikan berarti peningkatan mutu pembangunan di masa kini maupun di masa yang akan datang.

Salah satu mata pelajaran yang cukup penting guna meningkatkan mutu pendidikan, yaitu pelajaran matematika. Hal ini dikarenakan matematika merupakan pelajaran yang menuntut pola berpikir yang logis, rasional, kritis, dan sistematis. Salah satu cabang matematika yang dianggap sulit oleh siswa adalah Geometri. Geometri adalah cabang matematika yang berkaitan dengan bentuk, ukuran, komposisi dan proporsi suatu benda beserta sifat-sifatnya dan hubungannya satu sama lain. Dahlan (2011) menyatakan bahwa Geometri merupakan cabang matematika yang telah diakrabi oleh manusia sejak lahir dikarenakan Geometri ada dimana-mana di setiap tempat dan hamper di setiap objek visual.

Tujuan pembelajaran geometri adalah agar siswa memperoleh rasa percaya diri mengenai kemampuan matematikanya, menjadi pemecah masalah yang baik, dapat berkomunikasi secara matematik, dan dapat bernalar secara matematik (Bobango, 1993). Sedangkan Budiarto (2000) menyatakan bahwa tujuan pembelajaran geometri adalah untuk mengembangkan kemampuan berpikir logis, mengembangkan intuisi keruangan, menanamkan pengetahuan untuk menunjang materi yang lain, dan dapat membaca serta menginterpretasikan argumen-argumen matematik.

Di sekolah, Geometri tidak diajarkan secara khusus tetapi berada dalam satu kesatuan pembelajaran Matematika. Pada Kurikulum 2013, materi Geometri tertuang dalam beberapa Standar Kompetensi yang membahas tentang bentuk, ukuran dan posisi suatu objek baik pada dimensi 2 maupun dimensi 3. Materi-materi yang berkaitan dengan Geometri tersebut tentunya membutuhkan daya pikir dan daya visualisasi tingkat tinggi. Oleh sebab itulah siswa sering mengalami kesulitan dalam mempelajari materi-materi Geometri. Hal ini sesuai dengan pernyataan Dahlan (2011), kenyataannya di lapangan tidak sepenuhnya terjadi sesuai dengan yang diharapkan, ada gejala bahawa Geometri tidak 
banyak diminati oleh siswa. Geometri sering dianggap materi yang sulit untuk dipahami, sulit untuk mengerjakannya dan juga membosankan. Menurut Petrou \& Golding (2011), siswa SMP tidak sepenuhnya memahami konsep Geometri. Selain itu, Ojose (2011) menyatakan bahwa siswa memiliki keahlian minimum dalam Geometri. Hal ini sesuai dengan hasil penelitian Salman (2009) yang menyatakan bahwa dari 12 topik matematika, Geometri merupakan topik yang paling sulit bagi siswa.

Hal ini menunjukkan rendahnya kemampuan spasial siswa. Kemampuan spasial adalah kemampuan yang mencakup kemampuan berpikir dalam gambar, serta kemampuan untuk menyerap, mengubah dan menciptakan kembali berbagai macam aspek dunia visual. Kemampuan spasial sangat penting untuk ditingkatkan, hal ini berdasarkan pada hasil penelitian National Academy of Scince (Syahputra, 2011) yang mengemukakan bahwa setiap siswa harus berusaha mengembangkan kemampuan dan penginderaan spasialnya yang sangat berguna dalam memahami relasi dan sifat-sifat dalam Geometri untuk memecahkan masalah matematika dan masalah dalam kehidupan sehari-hari. Hal ini diperkuat dengan pendapat Giaquinto yang menyatakan persepsi dari suatu objek atau gambar dapat dipengaruhi secara ekstrim oleh orientasi objek tersebut. Sehingga dapat mengenali suatu objek/gambar dengan tepat diperlukan kemampuan spasial (Syahputra, 2011). Kecerdasan visual-spasial berkaitan dengan kemampuan menagkap warna, arah, ruang secara akurat. Musfiroh Sebagaimana dikemukakan Armstrong bahwa Siswa yang cerdas dalam visual spasial memiliki kepekaan terhadap warna, garis-garis, bentuk-bentuk, ruang dan bangunan (Widiyanto \& Rofiah, 2012).

Menurut Hamley (McGee, 1979) kemampuan Matematika adalah gabungan dari inteligensi umum, pembayangan visual, kemampuan untuk mengamati angka, konfigurasi spasial dan menyimpan konfigurasi sebagai pola mental. Dalam kemampuan spasial diperlukan adanya pemahaman kiri-kanan, pemahaman perspektif, bentuk-bentuk geometris, menghubungkan konsep spasial dengan angka, kemampuan dalam mentransformasi mental dari bayangan visual. Faktor - faktor tersebut juga diperlukan dalam belajar Matematika.

Gardner mengemukakan seperti yang dikutip Al Arif, bahwa kemampuan spasial adalah kemampuan untuk menangkap dunia ruang secara tepat atau dengan kata lain kemampuan untuk memvisualisasikan gambar, yang di dalamnya termasuk kemampuan 
mengenal bentuk dan benda secara tepat, melakukan perubahan suatu benda dalam pikirannya dan mengenali perubahan tersebut, menggambarkan suatu hal atau benda dalam pikiran dan mengubahnya dalam bentuk nyata, mengungkapkan data dalam suatu grafik serta kepekaan terhadap keseimbangan, relasi, warna, garis, bentuk, dan ruang (Syahputra, 2011).

Peranan kemampuan spasial terhadap Matematika disokong beberapa studi validitas. Hills (McGee, 1979) meneliti hubungan antara berbagai tes kemampuan spasial yang melibatkan visualisasi dan orientasi dari Guiford dan Zimmerman dengan nilai matematika Ditemukan ada korelasi yang tinggi antara kemampuan spasial dengan nilai Matematika, bila dibandingkan dengan tes verbal dan penalaran. Demikian pula studi yang dilakukan oleh Bishop (Syahputra, 2011), Benbow \& McGuinness (Geary, 1996) menemukan adanya hubungan antara pemecahan masalah matematika dengan kemampuan visuospasial.

Dalam mempelajari peran kemampuan spasial terhadap prestasi belajar matematika, Smith (1980) menyimpulkan bahwa antara kemampuan spasial dengan konsep matematika taraf tinggi terdapat hubungan yang positif, tetapi kurang mempunyai hubungan dengan perolehan konsep-konsep matematika taraf rendah seperti hitungan. Studi dari Sherman (1980) terhadap siswa usia sekolah, menemukan adanya hubungan yang posif antara prestasi belajar matematika dan kemampuan spasial. Penggunaan contoh spasial seperti membuat bagan, dapat membantu siswa menguasai konsep matematika. Menurut Newman, metode pengajaran matematika yang memasukkan berpikir spasial seperti bentuk-bentuk geometris, mainan (puzzle) yang menghubungkan konsep spasial dengan angka, menggunakan tugas-tugas spasial dapat membantu terhadap pemecahan masalah dalam matematika (Eliot, 1987). Demikian pula pengertian terhadap konsep pembagian, Clements menyatakan bahwa proporsi tergantung dari pengalaman spasial yang mendahuluinya (Eliot, 1987). Adapun indikator kemampuan spasial adalah adanya pemikiran perceptual, klasifikasi gambar, konsistensi logis dan adanya kemampuan identifikasi gambar.

Kecerdasan spasial menurut Shearer, meliputi kemampuan-kemampuan untuk mempresentasikan dunia melalui gambaran-gambaran mental dan ungkapan artistik (Syahputra, 2011). Agustin menyatakan bahwa kecerdasan spasial sebagai sekumpulan kemampuan-kemampuan yang berhubungan dengan pemilihan, pemahaman dimana 
proyeksi visual, imajinasi mental pemahaman ruang, manipulasi imajinasi, serta pengandaan imajinasi nayat maupun imanjinasi dalam diri/abstrak (Widiyanto \& Rofiah, 2012). Menurut Howard Gadner menguraikan deskripsi tentang kemampuan spasial seperti yang dikutip Agustin, kemampuan spasial adalah kemampuan memahami, memproses, dan berpikir dalam bentuk visual. Siswa dengan kemampuan ini mampu menerjemahkan bentuk gambaran dalam pikirannya ke dalam bentuk dua atau tiga dimensi (Widiyanto \& Rofiah, 2012). Menurut Abdurrahman seperti yang dikutip Apriani (Widiyanto \& Rofiah, 2012) ada lima jenis kemampuan spasial yaitu: (1) hubungan keruangan (spacial relation); (2) diskriminasi visual (visual discrimination); (3) diskriminasi bentuk latar belakang (figure-ground discrimination); (4) visual clouser; (5) mengenal objek (object recognition).

Ciri khusus dari kecerdasan spasial adalah pemahaman tentang arah, serta berpikir dan merencsiswaan sesuatu dalam tiga dimensi. Sedangkan ciri umum seorang siswa memiliki kemampuan spasial yang tinggi adalah sebagai berikut: (1) sangat senang bermain dengan bentuk dan ruang, seperti Puzzle dan balok; (2) Tidak mengalami kesulitan membaca peta; (3) lebih tertarik pada gambar dari pada tulisan; (3) peka terhadap warna; (4) suka fotografi atau videografi; (4) mampu membayangkan sebuah benda dilihat dari berbagai sudut; (5) imajinatif (suka membayangkan); (6) pandai menggambar.

Berdasarkan uraian diatas dapat disimpulkan bahwa kemampuan visual spasial sangat penting. Kemampuan tersebut dapat membantu siswa dalam proses belajar mengajar serta mengenali lingkungan sekitarnya. Misalnya kemampuan hubungan keruangan yang merupakan bagian sangat penting dalam belajar matematika khususnya geometri.

Geometri menempati posisi khusus dalam kurikulum matematika, karena banyaknya konsep-konsep yang termuat di dalamnya. Dari sudut pandang psikologi, geometri merupakan penyajian abstraksi dari pengalaman visual dan spasial, misalnya bidang, pola, pengukuran dan pemetaan. Sedangkan dari sudut pandang matematik, geometri menyediakan pendekatan-pendekatan untuk pemecahan masalah, misalnya gambar-gambar, diagram, sistem koordinat, vektor, dan transformasi. Geometri juga merupakan lingkungan untuk mempelajari struktur matematika (Burger \& Shaughnessy, 1986). Geometri merupakan salah satu cabang matematika. Dengan mempelajari geometri 
dapat menumbuhkan kemampuan berfikir logis, mengembangkan kemampuan memecahkan masalah dan pemberian alasan serta dapat mendukung banyak topik lain dalam matematika (Kennedy, 1994). Usiskin (Syahputra, 2011) mengemukakan bahwa geometri adalah (1) cabang matematika yang mempelajari pola-pola visual, (2) cabang matematika yang menghubungkan matematika dengan dunia fisik atau dunia nyata, (3) suatu cara penyajian fenomena yang tidak tampak atau tidak bersifat fisik, dan (4) suatu contoh sistem matematika.

Sementara itu, Geometri merupakan materi yang penting karena sangat berkaitan dengan kehidupan kita sehari-hari. Geometri merupakan materi yang termasuk ke dalam Ujian Nasional baik tingkat SMP maupun SMA. Hal ini sesuai dengan pendapat Sumarmo (2013) yang menyatakan: "Geometry was an important content in elementary school mathematics curriculum." yang berarti bahwa Geometri adalah pelajaran yang sangat penting di dalam kurikulum matematika sekolah menengah. Dahlan (2011) menyatakan bahwa belajar Geometri adalah hal yang krusial. Geometri merupakan materi yang perlu mendapat perhatian baik isi materi maupun pengajarannya. Geometri berhubungan satu sama lain mulai dari yang peling sederhana sampai yang rumit. Ada berbagai konsep dan prosedur matematik yang dijelaskan dengan menggunakan aturan-aturan Geometri, konsep-konsep Geometri dan bentuk-bentuk Geometri. Selanjutnya Turmudi (2012) menyatakan bahwa sistem Geometri dan tilikan ruang merupakan dua hal yang berkaitan erat dengan sistem bilangan dan cara berpikir numerik, sebagai pondasi untuk pengenalan lebih lanjut tentang matematika dasar dan matematika tinggi dan juga digunakan dalam berbagai bidang terapan (aplikasi). Oleh karena itu pembelajaran Geometri pada tingkat dasar khususnya sekolah menengah sangatlah penting untuk menunjang materi Geometri pada tingkat yang lebih tinggi lagi.

Kesulitan siswa dalam pembelajaran Geometri sebagai akibat dari rendahnya kemampuan spasial siswa, sementara Geometri merupakan salah satu pembelajaran yang penting dalam Matematika tentu saja merupakan suatu permasalahan yang harus untuk diatasi. Dalam hal ini penulis menawarkan solusi berupa pemanfaat media pembelajaran dengan menggunakan salah satu Software Matematika yang dinamis, yaitu Cabri 3D. Cabri 3D merupakan Software Matematika dinamis sebagai suatu media dimana siswa dapat mengembangkan, bereksperimen dan memanipulasi diagram-diagram geometris. 
Cabri 3D merupakan perangkat lunak dinamis-geometri yang dapat digunakan untuk membantu siswa dan guru untuk mengatasi beberapa kesulitan-kesulitan dan membuat belajar geometri dimensi tiga (geometri ruang) menjadi lebih mudah dan lebih menarik. Program Cabri 3D ini dpilih karena program ini dapat menunjukan gambaran bangun ruang secara lebih jelas, sehingga siswa dapat mengkonstrusi gagasan tentang konsep Volume Limas.

Penggunaan program Cabri $3 D$ sebagai langkah untuk meningkatkan kemampuan spasial yang diharapkan mampu meningkatkan hasil belajar siswa. Menurut Accascina \& Rogora (2006), Cabri 3D adalah perangkat lunak dinamis-geometri yang dapat digunakan untuk membantu siswa dan guru untuk mengatasi beberapa kesulitan-kesulitan dan membuat belajar geometri dimensi tiga (geometri ruang) menjadi lebih mudah dan lebih menarik.

Gambar yang terdapat pada program Cabri $3 D$ dapat digeser dan diputar sehingga dapat dilihat dari arah yang berbeda serta dapat menjukan bagian-bagian sikusiku yang terdapat pada bangun ruang tersebut. Selain itu, pembelajaran menggunakan program Cabri $3 D$ dikelas, dirasa menjadi lebih menarik dan tidak monoton sehingga mengugah motivasi belajar siswa agar proses pembelajaran menjadi lebih menyenangkan.

Wilson (Kusumah, 2011) mengatakan bahwa komputer dengan desain Software yang baik dapat menghadirkan presentasi secara berulang dan dinamis yang tidak dijumpai dalam media lainnya. Selain itu, menurut Glass (Kusumah, 2011) komputer dapat dimanfaatkan untuk mengatasi perbedaan individual, mengajarkan konsep, dan menstimulir belajar siswa. Sebagai media pembelajaran, komputer tidak hanya berfungsi sebagai pembawa nuansa baru, tetapi juga berperan dalam mengembangkan bakat, minat, dan kemampuan siswa dalam pelajaran matematika.

\section{METODE PENELITIAN}

Penelitian ini merupakan penelitian kuasi eksperimen dengan disain kelompok kontrol tidak ekivalen karena tidak adanya pengacakan dalam menentukan subyek penelitian, yaitu peneliti tidak membentuk kelas baru berdasarkan pemilihan sampel secara acak. Menurut Creswell (2010) disain kelompok kontrol tidak ekivalen (Non Ekuivalent Control - Group Design) adalah disain kelompok eksperimen dan kelompok kontrol 
diseleksi tanpa prosedur acak kemudian kedua kelompok sama-sama diberikan pre-test dan post-test, tetapi hanya kelompok eksperimen saja yang diberikan perlakuan. Ruseffendi (2005) menyatakan bahwa pada kuasi ekperimen, subyek tidak dikelompokkan secara acak tetapi peneliti menerima keadaan subyek seadanya.

Variabel bebas dalam penelitian ini adalah pembelajaran Geometri berbantuan Cabri 3D. Variabel terikatnya adalah kemampuan spasial siswa.

Tujuan penelitian ini adalah menguji pembelajaran Geometri berbantuan Cabri 3D. terhadap kemampuan spasial siswa. Disain penelitian ini diilustrasikan sebagai berikut:

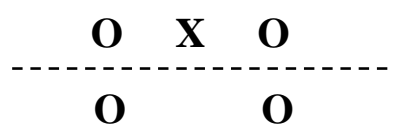

Keterangan:

O : Pretes / Postes Kemampuan Spasial

$\mathrm{X}$ : Pembelajaran Geometri berbantuan Cabri 3D.

- - - - - : Subyek tidak dikelompokkan secara acak

Populasi penelitian ini adalah seluruh siswa kelas VIII pada salah satu SMP Negeri di Kota Bandung. Populasi ini dipilih dengan pertimbangan bahwa siswa kelas VIII adalah siswa yang paling efektif untuk diteliti dibandingkan siswa kelas VII dan IX. Siswa kelas VII di beberapa sekolah sudah mengimplementasikan Kurikulum 2013 yang masih penuh dengan pro dan kontra dalam pelaksanaannya. Selain itu, siswa kelas VII baru mengenal lingkungan dan iklim belajar di sekolah menengah sehingga masih berada pada masa transisi dalam hal mengenal lingkungan dan suasana belajar yang baru serta adanya masa transisi dari sekolah dasar ke sekolah menengah. Sedangkan siswa kelas IX kurang efektif digunakan sebagai sampel sebab akan menghadapi Ujian Nasional.

Dari populasi dipilih dua kelas sebagai sampel penelitian yang akan dijadikan sebagai kelas Eksperimen dan kelas Kontrol. Pada kelas eksperimen dilaksanakan pembelajaran Geometri berbantuan Cabri 3D. Sedangkan pada kelas kontrol dilaksanakan pembelajaran konvensional.

Instrumen penelitian yang akan digunakan pada penelitian ini terdiri atas instrumen tes dan non-tes. Instrumen tes terdiri atas tes kemampuan spasial, sedangkan instrumen 
non-tes terdiri atas kuesioner/angket yang merupakan skala sikap siswa, observasi dan wawancara. Pemilihan instrumen ini adalah berdasarkan Triangulasi Data yang bertujuan untuk memastikan keabsahan data. tes kemampuan spasial yang dikembangkan dari Teori Gardner, sebanyak 25 item soal, yang terdiri dari 10 soal yang berkaitan dengan pemikiran perseptual, 5 soal yang berkaitan dengan klasifikasi gambar, 5 soal yang berkaitan dengan konsistensi logis dan 5 soal terakhir berkaitan dengan identifikasi gambar. Teknik non-tes digunakan untuk mengumpulkan data yang terkait dengan sikap siswa pada saat pembelajaran Geometri berbantuan Cabri 3D berlangsung. Angket digunakan untuk mengumpulkan data yang terkait dengan sikap siswa terhadap matematika. Untuk mengumpulkan data berupa aktivitas guru pada saat proses belajar-mengajar berlangsung, maka digunakan lembar observasi. Kemudian untuk mengetahui informasi mengenai pendapat, aspirasi, harapan, keinginan, dan keyakinan siswa terhadap matematika, maka penulis menggunakan teknik wawancara.

Pengumpulan data non-tes dalam penelitian ini dilakukan secara deskriptif dimana data yang dikumpulkan adalah bukan data berupa angka-angka. Data tersebut berasal dari catatan observasi, hasil wawancara, dokumen, foto, rekaman audio dan video yang diperoleh melalui angket, observasi, dan wawancara terkait sikap siswa.

Data tes terdiri pretes dan postes yang terlebih dahulu diperiksa validitas, reliabilitas, daya pembeda dan tingkat kesukaran soal lalu kemudian diujicobakan kepada siswa sehingga diperoleh data berupa jawaban-jawaban siswa terhadap soal uraian tersebut dengan teknik penilaian berdasarkan pedoman penskoran yang telah dipersiapkan sebelumnya. Selanjutnya dilihat gain dari data yang diperoleh, yaitu peningkatan kemampuan spasial siswa melalui data hasil pretes dan postes tersebut. Kemudian dilakukan analisis terhadap kemampuan spasial siswa mengenai konsep volume limas dengan cara melihat persentase setiap skor total yang diperoleh siswa.

Skala sikap diberikan kepada siswa pada kelas eksperimen setelah pretes dan postes dengan terlebih dahulu dilakukan analisis ketepatan skala butir angket skala sikap siswa. Skala sikap siswa ini menggunakan skala Likert dengan lima pilihan, yaitu: sangat sering (SS), sering (S), kadang-kadang (K), jarang (J) dan tidak pernah (TP) sehingga melalui instrumen ini diperoleh hasil berupa sikap siswa. 
Pemberian angket ini diikuti dengan wawancara dan observasi terhadap aktivitas siswa pada saat proses pembelajaran Geometri berbantuan Cabri $3 D$ sedang berlangsung. Hal ini berdasarkan Triangulasi Data yang bertujuan untuk memastikan keabsahan data.

Pelaksanaan penelitian diawali dengan memberikan pretes kepada kelas eksperimen dan kelas kontrol untuk mengetahui kemampuan awal siswa. Kemudian dilakukan pembelajaran Geometri berbantuan Cabri $3 D$ pada kelas eksperimen dan pembelajaran konvensional pada kelas kontrol. Setelah masing-masing kelas tersebut diberi perlakuan, tahap selanjutnya adalah memberikan postes yang kemudian hasilnya dianalisis berdasarkan langkah-langkah yang telah dipaparkan sebelumnya.

Prosedur penelitian ini terdiri atas 4 bagian, yaitu: (1) tahap persiapan; (2) tahap pelaksanaan; (3) tahap analisis data; (4) tahap kesimpulan. Pada tahap persiapan dilakukan penyusunan perangkat pembelajaran berupa RPP (Rencana Pelaksanaan Pembelajaran) baik dengan menggunakan Cabri $3 D$ maupun dengan pembelajaran konvensional. Selanjutnya dilakukan pengembangan instrumen, yaitu instrumen tes kemampuan spasial, skala sikap, observasi dan wawancara yang dikonsultasikan kepada dosen pembimbing. Untuk memperoleh kualitas instrumen yang baik makan seluruh intrumen diuji validitasnya. Pada tahap ini, instrumen tes kemampuan spasial secara diuji validitas, riabilitas, tingkat kesukaran soal dan daya pembeda.

Tahap selanjutnya adalah menentukan dua kelas yang akan digunakan sebagai kelas eksperimen dan kelas kontrol. Pemilihan kedua kelas ini berdasarkan saran, usulan serta pertimbangan guru matematika dan kepala sekolah.

Pada penelitian ini, peneliti berperan sebagai guru dengan pertimbangan untuk mengurangi bias mengenai terjadinya perbedaan perlakuan pada masing-masing kelas. Pada saat proses pembelajaran sedang berlangsung, peneliti dibantu oleh dua orang partner peneliti. Seorang partner berperan sebagai observer yang merupakan guru kelas dan seorang lagi adalah teman peneliti yang berperan dalam hal dokumentasi. Data yang diperoleh dari hasil penelitian kemudian dianalisis dengan berdasarkan langkah-langkah yang telah dipaparkan sebelumnya. Pengelompokan kemampuan awal siswa dilakukan berdasarkan kepada hasil ujian tengah semester diikuti dengan pertimbangan guru sehingga diperoleh siswa dengan kemampuan awal matematis dengan kategori tinggi, sedang dan rendah. 


\section{HASIL DAN PEMBAHASAN}

Hasil penelitian ini diperoleh dari data tes kemampuan spasial, lembar observasi dan wawancara. Tes kemampuan spasial diberikan kepada siswa di dua kelas sampel sebelum dan sesudah pembelajaran berlangsung (pretes dan postes). Lembar observasi digunakan pada saat proses pembelajaran sedang berlangsung untuk mengetahui bagaimana sikap dan perilaku baik guru maupun siswa. Wawancara oleh guru peneliti kepada siswa diberikan pada saat proses pembelajaran telah berlangsung dengan tujuan untuk mengetahui sikap dan perilaku siswa yang bertujuan sebagai cross-check terhadap hasil data tes, angket dan hasil observasi terhadap sikap siswa selama proses pembelajaran.

Kemampuan spasial siswa diperoleh melalui tes kemampuan spasial yang terdiri atas 5 butir soal berbentuk uraian yang sebelumnya telah dilakukan uji coba untuk menganalisis validitas, reliabilitas, tingkat kesukaran soal dan daya pembeda dengan bantuan Software Anates. Tes kemampuan spasial diberikan kepada siswa sebagai pretes, yaitu tes sebelum pembelajaran berlangsung dan sebagai postes, yaitu setelah pembelajaran berlangsung baik di kelas kontrol maupun kelas eksperimen. Pretes dan postes dilakukan untuk mengetahui peningkatan kemampuan spasial siswa pada kelas kontrol dan kelas eksperimen, dimana siswa pada kelas eksperimen memperoleh pembelajaran Geometri berbantuan Software Cabri 3D sedangkan siswa pada kelas kontrol memperoleh pembelajaran konvensional.

Data nilai rerata dan simpangan baku untuk data skor pretes, postes dan gain ternormaliasi dari kemampuan spasial siswa berdasarkan kategori kemampuan awal matematis disajikan pada tabel berikut:

Tabel 1. Deskripsi Statistik Data Kemampuan Spasial Siswa Berdasarkan Kemampuan Awal Matematis

\begin{tabular}{|c|c|c|c|c|c|c|c|c|c|c|}
\hline \multirow{3}{*}{$\begin{array}{l}\text { Jenis } \\
\text { Kemampuan }\end{array}$} & \multirow{3}{*}{ KAM } & \multirow{3}{*}{$\begin{array}{l}\text { Data } \\
\text { Stat. }\end{array}$} & \multicolumn{8}{|c|}{ Kelas Penelitian } \\
\hline & & & \multicolumn{4}{|c|}{ Eksperimen } & \multicolumn{4}{|c|}{ Kontrol } \\
\hline & & & pretes & postes & $\langle\mathbf{g}\rangle$ & $\mathbf{N}$ & pretes & postes & $\langle\mathrm{g}\rangle$ & $\mathbf{N}$ \\
\hline \multirow{7}{*}{ 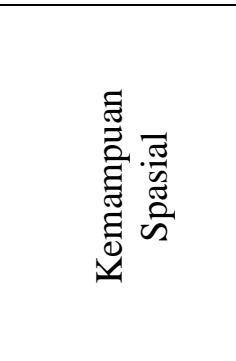 } & \multirow{2}{*}{ Tinggi } & $\overline{\bar{x}}$ & 35.83 & 79.79 & 0.73 & \multirow{2}{*}{6} & 25.42 & 67.29 & 0.58 & \multirow{2}{*}{6} \\
\hline & & $S$ & 7.53 & 19.34 & 0.24 & & 17.00 & 10.47 & 0.14 & \\
\hline & \multirow{2}{*}{ Sedang } & $\overline{\boldsymbol{x}}$ & 24.58 & 62.57 & 0.52 & \multirow{2}{*}{18} & 20.00 & 52.70 & 0.40 & \multirow{2}{*}{19} \\
\hline & & $S$ & 10.68 & 18.80 & 0.24 & & 12.14 & 12.97 & 0.19 & \\
\hline & \multirow{2}{*}{ Rendah } & $\bar{x}$ & 20.07 & 61.25 & 0.49 & \multirow{2}{*}{6} & 19.42 & 60.25 & 0.35 & \multirow{2}{*}{6} \\
\hline & & $S$ & 9.70 & 15.61 & 0.19 & & 12.56 & 12.42 & 0.25 & \\
\hline & Keseluruhan & $\overline{\boldsymbol{x}}$ & 25.83 & 79.79 & 0.73 & 30 & 20.00 & 67.29 & 0.58 & 31 \\
\hline
\end{tabular}




\begin{tabular}{cccccccc}
\hline & $S$ & 7.53 & 19.34 & 0.24 & $\begin{array}{c}12.14 \\
100\end{array}$ & 10.47 & 0.14 \\
Skor Maksimal Ideal & & & \multicolumn{5}{c}{} \\
\hline
\end{tabular}

Berdasarkan tabel di atas, dapat diketahui bahwa rata-rata nilai pretes kelas eksperimen adalah 25,83 lebih kecil daripada kelas kontrol yaitu sebesar 20,00. Kemudian rata-rata postes kelas eksperimen adalah 79,79 , lebih besar daripada rata-rata postes kelas kontrol yaitu 67,29. Rata-rata skor pretes kelas eksperimen maupun kelas kontrol berada sangat jauh dari skor maksimal ideal, yaitu 100. Hal ini dapat dimaklumi karena pengetahuan mengenai materi matematika yang diujikan pada kedua kelas tersebut belum pernah diperoleh siswa sebelumnya.

Untuk melihat gambaran peningkatan kemampuan spasial siswa berdasarkan Kemampuan Awal Matematis siswa, berikut ini disajikan diagram rerata n-gain kemampuan spasial siswa antara kelas kontrol dan kelas eksperimen berdasarkan kemampuan awal matematis (KAM):

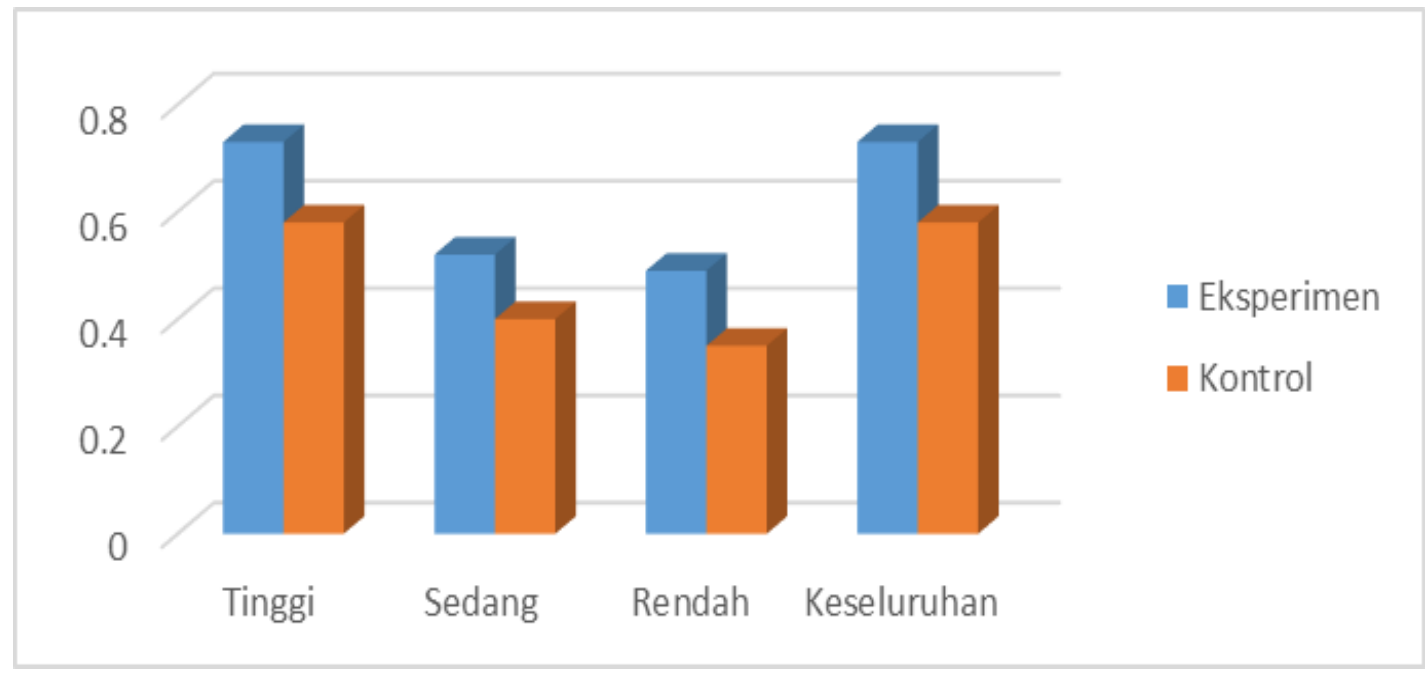

Gambar 1. Diagram Batang Skor N Gain Kemampuan Spasial Berdasarkan KAM

Berdasarkan gambar di atas dapat diketahui bahwa nilai rata-rata n-gain kelas kontrol untuk siswa berkemampuan tinggi sebesar 0,58, siswa berkemampuan sedang sebesar 0,40 dan siswa berkemampuan rendah sebesar 0,35 . Nilai rata-rata n-gain kelas eksperimen untuk siswa berkemampuan tinggi sebesar 0,73 , siswa berkemampuan sedang sebesar 0,52 dan siswa berkemampuan rendah sebesar 0,49. Dapat disimpulkan bahwa nilai rata-rata n-gain terbesar berada pada kelas eksperimen untuk siswa berkemampuan tinggi, yaitu sebesar 0,73 . Nilai rata-rata n-gain terkecil juga berada pada kelas eksperimen untuk siswa berkemampuan rendah, yaitu sebesar 0,35. 
Uji hipotesis dilakukan dengan menggunakan bantuan Software SPSS 20. Skor ngain pada kelas kontrol dan kelas eksperimen berdistribusi normal dan memiliki varians yang sama (homogen) sehingga untuk menguji perbedaan rerata skor n-gain dilakukan dengan menggunakan uji parametrik, yaitu uji-t. Berikut ini adalah jabaran hasil uji-t skor n-gain:

Tabel 2. Jabaran Hasil Uji-t Skor N-gain

\begin{tabular}{ccccc}
\hline & \multicolumn{1}{c}{ t-test for Equality of Means } & \multirow{2}{*}{ Kesimpulan } & \multirow{2}{*}{ Deskripsi } \\
\hline $\mathbf{T}$ & $\boldsymbol{d f}$ & Sig. (2-tailed) & & \\
\hline 2,305 & 59 & 0,025 & $\mathrm{H}_{0}$ ditolak & Ada perbedaan \\
\hline
\end{tabular}

Berdasarkan tabel di atas dapat diketahui bahwa nilai Sig. $=0,025<\alpha=0,05$ sehingga $\mathrm{H}_{0}$ ditolak. Artinya terdapat perbedaan peningkatan kemampuan spasial yang signifikan antara siswa yang belajar dengan menggunakan pendekatan Open-Ended daripada menggunakan pembelajaran konvensional.

Selanjutnya untuk mengetahui apakah peningkatan kemampuan spasial siswa dengan menggunakan pendekatan Open-Ended lebih baik daripada menggunakan pembelajaran konvensional, maka dapat dilihat dengan cara membandingkan nilai t hitung dengan t tabel.

Berdasarkan tabel di atas dapat diketahui bahwa nilai t hitung $=2,305$ dan derajat kebebasan $($ degree of freedom $=d f)=61-2=59$ dengan taraf signifikansi $5 \%=0,05$ diperoleh nilai $\mathrm{t}$ tabel $=2,000995$ sehingga $\mathrm{t}$ hitung $=2,305>2,000995=\mathrm{t}$ tabel. Oleh sebab itu, dapat disimpulkan bahwa peningkatan kemampuan spasial siswa dengan menggunakan pmbelajaran berbantuan Cabri 3D lebih baik daripada menggunakan pembelajaran konvensional.

Uji hipotesis dilakukan dengan menggunakan bantuan Software SPSS 20. Skor ngain berdasarkan KAM pada kelas kontrol dan kelas eksperimen secara keseluruhan berdistribusi normal dan memiliki varians yang sama (homogen) sehingga untuk menguji perbedaan rerata skor n-gain berdasarkan KAM dilakukan dengan menggunakan uji parametrik, yaitu uji Anova dua jalur. Berikut ini adalah jabaran hasil uji Anova dua jalur skor n-gain berdasarkan KAM:

Tabel 3. Jabaran Hasil Uji Anova Dua Jalur Skor N-gain Berdasarkan KAM

$\begin{array}{lllll}\text { Faktor } & \text { F } & \text { Sig. } & \text { Kesimpulan } & \text { Deskripsi }\end{array}$




\begin{tabular}{ccccc}
\hline Kelas & 4,782 & 0,008 & Ho ditolak & Ada Perbedaan \\
Kategori KAM & 4,717 & 0,000 & Ho ditolak & Ada Perbedaan \\
Kelas*KAM & 0,022 & 0,067 & Hoditerima & Tidak Ada Interaksi \\
\hline
\end{tabular}

Berdasarkan tabel di atas dapat diketahui bahwa nilai signifikansi Kelas, yaitu pendekatan pembelajaran $=0,008<\propto=0.05$ sehingga $\mathrm{H}_{0}$ ditolak. Artinya, terdapat perbedaan peningkatan kemampuan spasial antara siswa yang memperoleh pembelajaran berbantuan Cabri $3 D$ dengan siswa yang memperoleh pembelajaran konvensional. Hal ini menunjukkan bahwa faktor kelas yaitu jenis pembelajaran memberikan pengaruh yang signifikan terhadap peningkatan kemampuan berpikir kreatif siswa.

Hasil ini mendukung data sebelumnya, yaitu hasil analisis deskriptif dan uji-t terhadap peningkatan kemampuan spasial siswa yang menunjukkan bahwa peningkatan kemampuan spasial siswa pada pembelajaran Geometri berbantuan Cabri 3D lebih baik daripada menggunakan pembelajaran konvensional.

Selanjutnya, berdasarkan tabel 4 di atas dapat diketahui bahwa nilai signifikansi untuk faktor kategori kemampuan awal matematis $(\mathrm{KAM})=0,000<\propto=0,05$ sehingga $\mathrm{H}_{0}$ ditolak. Artinya, terdapat perbedaan peningkatan kemampuan spasial antara siswa yang memperoleh pembelajaran Geometri berbantuan Software Cabri 3D dengan pembelajaran konvensional ditinjau dari kemampuan awal matematis (KAM) siswa. Hal ini menunjukkan bahwa kemampuan awal matematis (KAM) memberikan pengaruh yang signifikan terhadap peningkatan kemampuan spasial siswa.

\section{KESIMPULAN}

Berdasarkan hasil analisis data, kesimpulan yang dapat diambil adalah sebagai berikut:

1. Secara keseluruhan, peningkatan kemampuan spasial siswa yang memperoleh pembelajaran matematika dengan menggunakan Software Cabri 3D lebih baik daripada pembelajaran konvensional.

2. Perbedaan kemampuan awal matematis siswa memberikan pengaruh yang signifikan terhadap peningkatan kemampuan spasial siswa. 
3. Peningkatan kemampuan spasial siswa yang memperoleh pembelajaran matematika dengan menggunakan Software Cabri $3 D$ lebih baik daripada pembelajaran konvensional berdasarkan Kemampuan Awal Matematis (KAM) siswa.

4. Tidak terdapat interaksi yang signifikan antara faktor pembelajaran (menggunakan Software Cabri 3D) dan kategori Kemampuan Awal Matematis siswa terhadap peningkatan kemampuan spasial.

5. Terdapat asosiasi atau hubungan yang positif antara kemampuan spasial dengan sikap siswa.

\section{DAFTAR PUSTAKA}

Accaciana, G \& Rogora. (2006). Using Cabri 3D Diagrams For Teaching Geometry. Internatinal Journal for Technology in Mathematics Education. Vol. 13(1), 1-11.

Burger, W. F. \& Shaughnessy, J. M. (1986). Characterizing the van Hiele Levels of Development in Geometry. Journal for Research in Mathematics Education. 17(I), 31-48.

Bobango, J. C. (1993). Geometry for All Student: Phase-Based Instruction. Dalam Cuevas (Eds). Reaching All Students With Mathematics. Virginia: The National Council of Teachers of Mathematics,Inc.

Budiarto, M. T. (2000). Pembelajaran Geometri dan Berpikir Geometri. Dalam prosiding Seminar Nasional Matematika "Peran Matematika Memasuki Milenium III". Jurusan Matematika FMIPA ITS Surabaya. Surabaya, 2 Nopember 2000.

Creswell, J. W. (2010). Research Design: Pendekatan Kualitatif, Kuantitaif, dan Mixed. (Achmad Fawaid, Penerjemah). Yogyakarta: Pustaka Pelajar.

Dahlan, J. A. (2011). Analisis Kurikulum Matematika. Jakarta: Universitas Terbuka.

Eliot, J. (1987). Model of Psychological Space: Psychometric, Developmental and Experimental Approaches. New York: Springer-Verlag.

Geary, D. C. (1996). Children's Mathematical Development. Washington: American Psychological Association.

Kennedy, L. M. (1994). Guiding Children's Learning of Mathematics. Tanpa Kota: Wadswarsh Publishing Company.

Kusumah, Y. S. (2011). Aplikasi Teknologi Informasi dan Komunikasi dalam Pembelajaran Matematika untuk Meningkatkan Kemampuan Matematis Siswa. Makalah disajikan dalam Kegiatan Pelatihan Aplikasi Teknologi dan Komunikasi dalam Pembelajaran Matematika tanggal 16 Desember 2011.

McGee, M. F. (1979). Human Spatial Ability: Psychometric Studies and Environment: Genetic, Hormonal, and Neurological Influences. Psychological Bulletin. 5, 887902.

Ojose, B. (2011). Mathematics Literacy: Are We Able to Put the Mathematics We Learn Into Everyday Use?. Journal of Mathematics Education. Vol. 4 (1), 89-100.

Petrou, M \& Goulding, M. (2011). Conceptualising Teachers' Mathematical Knowledge in Teaching, Springer Science+Business Media. Australia: Monash University.

Ruseffendi, H. E. T. (2005). Dasar-Dasar Penelitian Pendidikan dan Bidang Non-Eksakta Lainnya. Bandung: Tarsito. 
Salman, M. F. (2009). Active Learning Techniques (ALT) in A Mathematics Workshop; Nigerian Primary School Teachers' Assessment. International Electronic Journal of Mathematics Edication (IEJME). Vol 4 (1), 109-116.

Sherman, J. A. (1980). Mathematics, Spatial Visualization, and Related Factors: Changes in Girl and Boys grade 8-11. Journal of Educational Psychology. 72, 476-482.

Smith, P. K. (1980). Spatial Ability. London: University of London Press.

Sumarmo, U. (2013). Pengembangan Kemampuan dan Disposisi Berpikir Kritis dan Kreatif Peserta Didik dalam Pembelajaran Matematika. FPMIPA: UPI.

Syahputra, E. (2011), Peningkatan Kemampuan Spasial dan Disposisi berpikir kreatif siswa SMP dengan Pendekatan PMRI pada Pembelajaran Geometri Berbantuan Komputer. Disertasi. UPI Bandung: Tidak diterbitkan.

Turmudi. (2012). Matematika: Landasan Filosofis, Didaktis, dan Pedagogis Pembelajaran Matematika untuk Siswa Sekolah Dasar. Jakarta: Dirjen Pendidikan Islam Kementrian Agama RI.

Widiyanto, R. M \& Rofiah, B. (2012). Pentingnya Kecerdasan Spasial dalam Pembelajaran Geometri. [Online]. Tersedia di: https://rendikwidiyanto.wordpress.com/2012/11/07/pentingnya-kecerdasan-spasialdalam-pembelajaran-geometri/ [6 Agustus 2015] 